\title{
教育講演 IV
}

\section{$\mathrm{M}-\mathrm{CSF}$ の基礎と臨床}

\author{
元吉 和夫 \\ 防衛医科大学校第 3 内科 \\ "Basic and clinical studies on M-CSF"
}

Kazuo Motoyoshi

The Third Department of Internal Medicine, National Defense Medical College

Macrophage colony-stimulating factor (M-CSF) was found in 1978 by our group as a homodimeric glycoprotein with a molecular weight of $85 \mathrm{kDa}$ in human urine which stimulated macrophage colony formation in in vitro culture system of human and mouse bone marrow cells, and its gene was cloned by our group in collaboration with Genetics Institute in 1987. In vitro studies showed that M-CSF stimulated proliferation and differentiation of macrophage progenitor cells, and activated functions of mature macrophages such as killing of bacteria and fungi, production of granulocyte-macrophage $\mathrm{CSF}$, granulocyte $\mathrm{CSF}$, interleukin 6 and 8 , tumor necrosis factor and reactive nitrogen intermediates, and cholesterol metabolism. In addition to the effects on macrophages, $M$ -CSF was also found to stimulate proliferation and differentiation of trophoblasts and osteoclasts. Based on these basic studies, we conducted a large scale double blind clinical study using M-CSF and placebo, and found that administration of M-CSF to patients with acute myeloid leukemia after intensive chemotherapies accelerates recovery of neutrophils and platelets, reduces incidence and period of febrile neutropenia, total volumes of platelets transfused, and period requied to finish three courses of consolidation therapies with a statistic significances. It was also found that administration of $\mathrm{M}$-CSF reduced relapse rate and increased disease-free survival rate of younger AML patients (15-29 years old) with statistic significances. More recently, it was found that administration of $\mathrm{M}-\mathrm{CSF}$ to patients with ovarian cancers after intensive chemotherapies following operations in which tumors were completely removed, shortened periods required to finish two courses of chemotherapies and increased survival rate with statistic significances. These results indicate that administration of M-CSF not only stimulates hematopoiesis after cancer chemotherapy, but also induces anti-tumor immunity against cancer cells.

Key words : M-CSF, op/op mouse, WHHL rabbit, double blind test, disease-free survival 


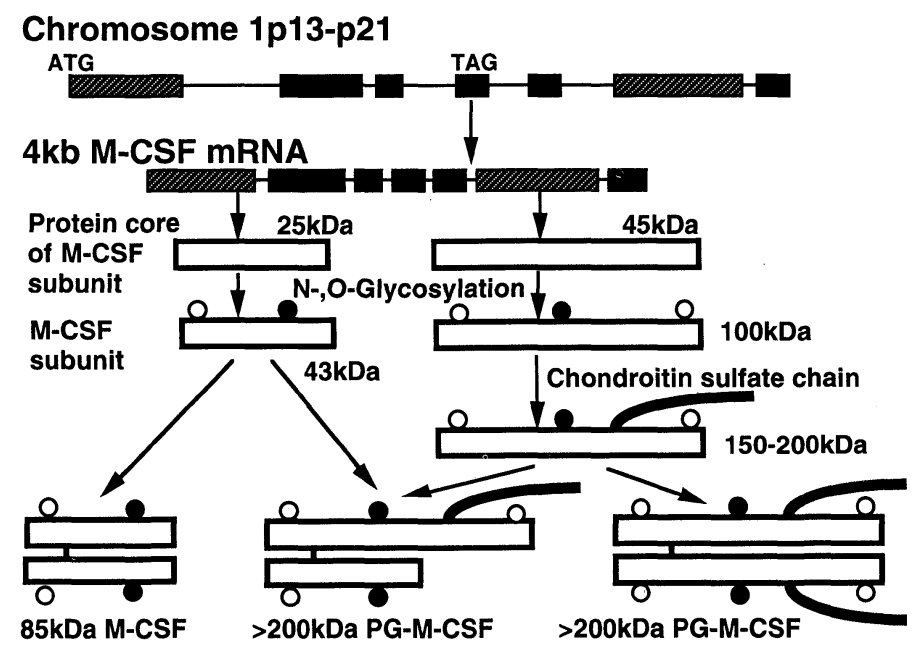

図 $1 \mathrm{M}-\mathrm{CSF}$ 遺伝子から 3 種類の M-CSF 分子が生合成される過程

表 1 M-CSF の多彩な生物活性

1. 造血刺激活性

a. 単球の増殖と分化を刺激し, 生存期間を延長する

b. 単球の細菌や真菌に対する殺菌能を刺激する

c. 単球の GM-CSF (Granulocyte-macrophage colony-stimulating factor) と G-CSF (Granulocyte CSF)の産生をプライミングするこ とによって好中球の産生を刺激する

d. 単球の IL-8 (Interleukin 8) 産生を増幅することによって好中球の 殺菌能を刺激する

e. 単球の GM-CSF と IL-6産生をプライミングすることによって血小 板の産生を刺激する

f. RNI (Reactive nitrogen intermediate) 産生を増幅することによっ

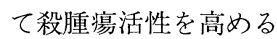

g. TNF(Tumor necrosis factor)産生をプライミングすることによ って殺腫瘍活性を高める

2. 緁毛細胞の増殖と分化を刺激する

3. 破骨細胞の増殖と分化を刺激する

4. 脂質代謝刺激活性

a. 単球の LDL (Low-density lipoprotein)受容体およびスカベンジャ 一受容体の発現を高めることによって LDL および変性 LDL の取り 込みを促進する

b. 単球のコレステロールエステル分解酵素を活性化するとともに, HDL (High-density lipoprotein) 受容体の発現を高めることによっ て LDL の逆転送を促進する

c. WHHL(Watanabe heritable hyperlipidemic)ウサギにおいて動 脈硬化進展を防止する 


\section{M-CSF の発見と遺伝子クローニング}

1978年筆者らはヒ卜尿中に in vitro でマウス骨䯣 細胞によるマクロファージコロニ一形成を刺激する 因子を発見して CSF-HU (Colony-stimulating factor from human urine) と命名した1)。最終精製標 品は $2 \times 10^{8} \mathrm{U} / \mathrm{mg}$ 蛋白の比活性をもつた分子量 85 $\mathrm{kD}$ の糖蛋白質であり, 分子量 $43 \mathrm{kD}$ のサブユニット のホモ 2 量体であった ${ }^{2)}$ 。いで1987年筆者らは米 国の Gordon G. Wong (Genetics Institute 社, Boston）らと共同で CSF-HU の遺伝子クローニングに 成功した3)。CSF-HUの CDNA（p3 ACSF-69）は 3981個のヌクレオチドからなり1個の open reading frameをもっており，その5側に signal peptide 配列を持っていた。遺伝子組換え型 CSF-HU が大量に調製され in vitroおよび in vivoの実験が 進むにつれて, CSF-HUが macrophage CSF $(\mathrm{M}$ $\mathrm{CSF})$ と呼ぶにふさわしいサイトカインであること が判明したので, 筆者らは第16回国際実験血液学会 （1987年，東京）および国際モノカインワークショ ップ (1987年, South Carolina) において,「CSF$\mathrm{HU}$ を M-CSF と命名する」ことを提唱して承認さ れた。

M-CSF 遺伝子は七卜第 1 番染色体 $1 \mathrm{p} 13-\mathrm{p} 21$ 領 域に 1 コピー存在し, それから $4 \mathrm{~kb}$ mRNA がつく られ，それ以後図 1 に示すようなプロセスを経て 3 種類の成熟型 M-CSF が産生される。このうち $85 \mathrm{kD}$ -M-CSF は可溶型であり血中に存在するが4), 2 種 類の PG-M-CSF はコンドロイチン硫酸鎖を介して 組織の細胞外マトリックスの V 型コラーゲンと結 合して存在する組織結合型である5)6)

\section{可溶型 M-CSF の生物活性（表 1 参照）}

\section{1. 造血刺激活性}

$\mathrm{M}-\mathrm{CSF}$ は単球の増殖，分化を刺激するだけでな く, 単球の細菌や真菌に対する殺菌能を刺激すると ともに, 単球の GM-CSF や G-CSF 産生をプライミ ングすることによって好中球産生を刺激する7)。さ らに単球の IL-8 産生を刺激することによって好中 球の殺菌能を刺激する ${ }^{8)}$ 。

M-CSF は単球の GM-CSF と IL-6 産生をプラ イミングすることによって血小板産生も刺激する。 M-CSF は単球の RNI(Reactive nitrogen intermediate) 産生を刺激したり, 腫瘍壊死因子 (TNF)の 産生をプライミングすることによって単球の殺腫瘍

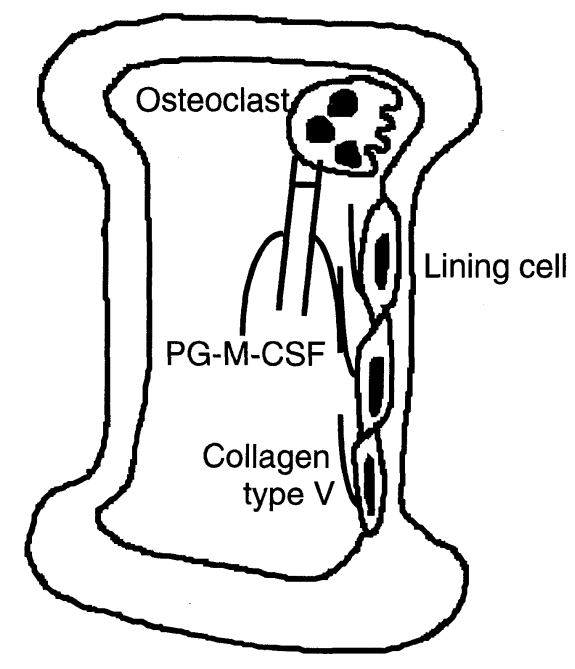

図 2 骨吸収における $\mathrm{PG}-\mathrm{M}-\mathrm{CSF}$ の役割 骨の Lining cellの細胞外マトリック スのV 型コラーゲンとコンドロイチ ン硫酸鎖を介して結合して局在する PG-M-CSF は破骨細胞を骨の表面に 呼び込んで骨吸収を刺激すると考えら れる

活性を増強する ${ }^{9110)}$ 。最近 M-CSF をマウスに投与 すると脾臟に NK 細胞が誘導されることが明らか となった ${ }^{11)}$ 。

\section{2. 絨毛細胞分化作用}

妊娠に際して胎盤脱落膜や絨毛細胞で大量の MCSF が産生されるが，これは未熟な単核の絨毛細胞 (cytotrophoblast) が細胞融合を繰り返しながら多 核の成熟した合胞体細胞（syncytiotrophoblast） 分化する過程に M-CSF が必須の因子であるためで ある12)。この胎盤局所での M-CSF の大量産生は当 然母体の高 M-CSF 血症をひきおこし，母体は感染 症が無くても白血球増加症となる（妊娠性白血球増 加症) ${ }^{13)}$ 。

3. 破骨細胞増殖分化作用

大理石病モデル動物である op/op マウスにおい て M-CSF 遺伝子内に点突然変異が起こっており， そのため機能を持たない短い M-CSF が産生されて

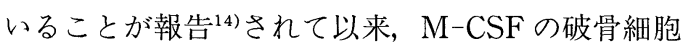
への作用について多くの研究が行われ, 現在では $\mathrm{M}$ -CSF が破骨細胞前駆細胞の増殖と分化に必須の因 

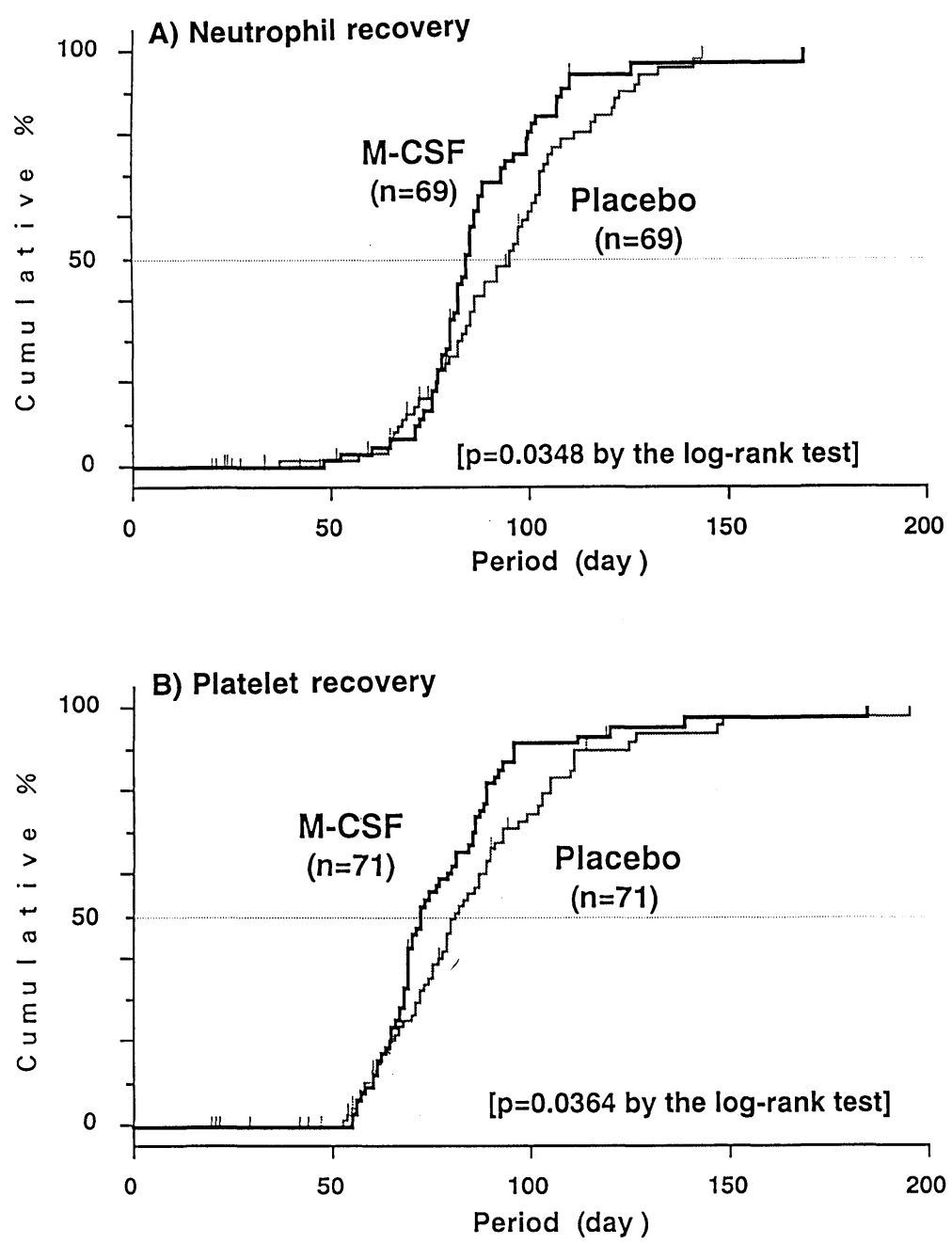

図 $3 \mathrm{AML}$ 患者の地固め療法後の好中球と血小板回復に及ぼす M-CSF の投与 効果（文献23）
A）化学療法開始から好中球が 1,000 に回復するまでの日数
B）化学療法開始から血小板が 10 万に回復するまでの日数

子であることが in vitro で証明されている ${ }^{15)}$ 。事実 op/op マウスを M-CSF で治療すると骨に破骨細胞 が, また末梢血に単球が出現し, 大理石病を完全に 直すことができる。このことは破骨細胞と単球は共 通の前駆細胞から産生されることを示している。

4. 脂質代謝促進作用

筆者らが小児慢性好中球減少症患者に対する $\mathrm{M}-$
$\mathrm{CSF}$ の好中球増加効果を調べるための臨床試験を 実施していた時，M-CSF 投与を受けた患者全員に おいて血清総コレステロールが-9.5〜-33.9\%も減 少していることに気づいた16)。それ以後 M-CSF の 脂質代謝に及ぼす影響について in vitroおよび in vivo での研究が進展し，M-CSF が(1)マクロファー ジの低比重リポプロテイン (LDL) 受容体およびス 
表 2 M-CSF とプラセボを用いた 2 重盲検試験の結果

\begin{tabular}{|l|c|c|c|}
\hline & プラセボ群 & M-CSF 群 & \\
\hline 登録症例数 & 101 & 97 & \\
\hline 適格症例数 & 94 & 90 & \\
\hline 解析対象症例数 & 94 & 88 & \\
\hline $\begin{array}{c}\text { 好中球回復の } \\
\text { 中央值 (日) }\end{array}$ & 96 & 85 & $\mathrm{p}=0.0348$ \\
\hline 総感染頻度 (回) & 185 & 133 & $\mathrm{p}=0.0206$ \\
\hline 総感染日数 (日) & 977 & 565 & $\mathrm{p}=0.0029$ \\
\hline $\begin{array}{c}\text { 血小板回復の } \\
\text { 中央值 (日) }\end{array}$ & 81 & 72 & $\mathrm{p}=0.0364$ \\
\hline $\begin{array}{c}\text { 血小板輸血頻度の } \\
\text { 中央值 }\end{array}$ & 1 日)
\end{tabular}

カベンジャ一受容体の発現を高めることによって LDL および変性 LDL の取り込みを促進する ${ }^{17)}$, (2) マクロファージのコレステロールエステル分解酵素 を活性化するとともに，HDL 受容体の発現を高め ることによって LDLの逆転送も促進することが明 らかとなった。そこで M-CSF をヒトの家族性高コ レステロール血症のモデル動物であるWHHL

(Watanabe heritable hyperlipidemic) ウサギに長 期間投与したところ M-CSF 群では明らかに動脈硬 化の進展が抑制されていた ${ }^{18)}$ 。

\section{プロテオグリカン型 M-CSF}

1992年筆者の研究グループのSuzu らは組織の細 胞外マトリックスと結合して存在するプロテオグリ カン型 M-CSF (PG-M-CSF) を発見した（図 1参 照) ${ }^{5) 6)}$ 。PG-M-CSF はその分子構造から判るように 85kD-M-CSF の全ての生物活性を持っているだけ でなく，付加的 C-末端ぺプチドを持っていること と，そこにコンドロイチン硫酸鎖が結合しているこ となどの構造的特異性をもっていることから ${ }^{19)}, 85$ $\mathrm{kD}-\mathrm{M}-\mathrm{CSF}$ には無い $\mathrm{PG}-\mathrm{M}-\mathrm{CSF}$ 特異的生物活性 を持っている。 $\mathrm{PG}-\mathrm{M}-\mathrm{CSF}$ 特異的生物活性として
は次のようなものがある。(1)骨の lining cell は MCSF を産生するが, 産生された $85 \mathrm{kD}-\mathrm{M}-\mathrm{CSF}$ は骨 髄腔内に拡散していくが，PG-M-CSF は細胞外マ トリックスの V 型コラーゲンと結合して局所に存 在するので，その周りに破骨細胞が集まって来て骨 吸収が進行する (図 2) ${ }^{20)}$, (2) PG-M-CSF は血清中 の LDL と結合するが，その結合は PG-M-CSF の コンドロイチン硫酸鎖と LDL の Apo-B との結合 である21), (3) PG-M-CSF は basic Fibroblast growth factor (bFGF) と結合するが，その結合は $\mathrm{PG}-\mathrm{M}-\mathrm{CSF}$ の付加的 C-末端ぺプチド部分と bFGF のへパリン結合部位との結合である。この PG-M-CSF の bFGF への結合は, bFGF の線維芽 細胞增殖刺激活性を容量依存性に抑制寸る ${ }^{22)}$ 。

\section{M-CSF の臨床応用}

すでに述べたごとく，M-CSF は(1)骨髄における 単球産生を刺激するだけでなく, 単球の殺菌能を活 性化する, (2)単球の GM-CSF と G-CSF 産生をプラ イミングすることによって好中球産生を刺激すると ともに，単球の IL-8 産生を刺激することによって 好中球の殺菌能を活性化する, (3)単球の GM-CSF 


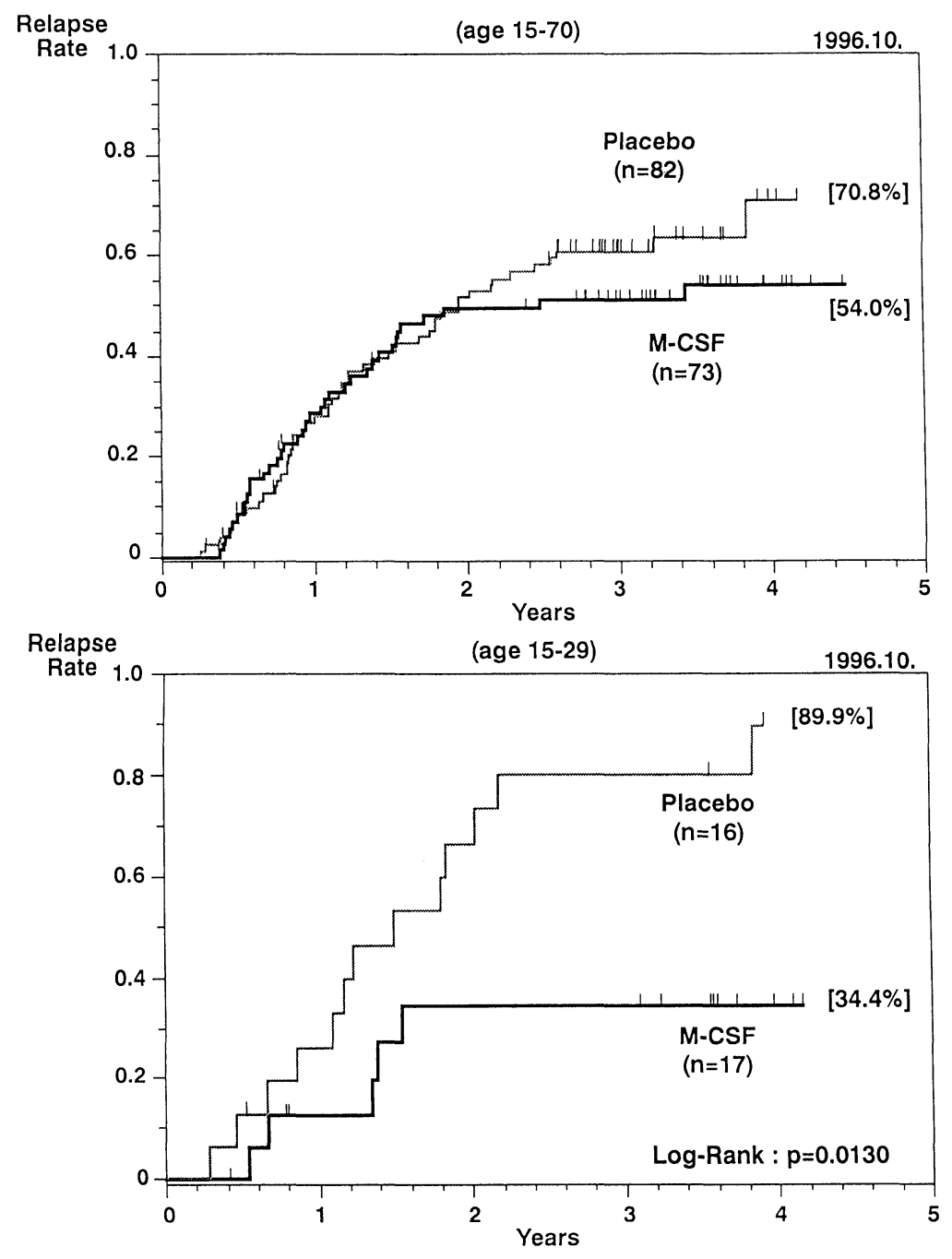

図 4 AML 患者の白血病再発率(15 70歳と15 29歳, 1996年10月現在) (文献24)

と IL-6 産生をプライミングすることによって血小 板産生を刺激する，(4)単球の RNI 産生を刺激し, TNF 産生をプライミングすることによって単球の 殺腫瘍活性を刺激する，などの活性を持っている。 したがって抗癌剂投与を受けた癌患者に M-CSF を 投与すると, (1)好中球回復の促進と感染症の防止, (2)血小板回復の促進と血小板輸血量の減少, それに (3)癌の再発を防止し, 無病生存率を高める, などの 臨床効果が期待されていた。
そこで筆者らは M-CSF の臨床効果を証明するた めに, AML 患者と卵巣癌患者において, M-CSF と プラセボを用いた大規模二重盲検試験を実施した。

1. M-CSF の AML 患者での 2 重盲検試験 1992年から1994年にかけて JALSG (Japan Adult Leukemia Study Group）によって M-CSF の臨床 的有用性を評価するため大規模 2 重盲検比較試験が 実施された ${ }^{23)}$ 。この結果 M-CSF の臨床投与が, (1)好中球が 1,000 に回復する日数と血小板が 10 万に 
回復する日数を短縮する（図 3 ),

(2)感染症の頻度と日数を減少させる，

(3)血小板輸血の頻度と輸血量を減少させる,

(4) 3 回の地固め療法を終了するのに要する日数を短 縮する，などの点が統計的有意差をもって証明され た（表 2 ）。さらにこの 2 重盲検試験に登録された AML 患者の無病生存率はプラセボ群 $28.9 \%$ に対し て M-CSF 群43.8\%と M-CSF 群で高く, 30歳未満 の患者群ではプラセボ群 $10.1 \%$ に対して M-CSF 群 $65.6 \%$ と統計的有意 $(\mathrm{p}=0.0130)$ に-CSF 群で無 病生存率が高かった。そこで M-CSF 群とプラセボ 群の AML 再発率を比較すると,プラセボ群70.8\%, M-CSF 群 $54.0 \%$ と M-CSF 群で約 $17 \%$ 低く，特に 30歳未満の患者群では M-CSF 群の再発率 (34.4\%) の方がプラセボ群の再発率 $(89.9 \%)$ より統計的有 意 $(\mathrm{p}=0.013)$ に低かった (図 4$)^{24)}$ 。

\section{文}

1) Motoyoshi K, Takaku F, Mizoguchi H, et al: Purification and some properties of colonystimulating factor from normal human urine. Blood 52 : 1012-1020 1978

2) Hatake K, Motoyoshi K, Ishizaka Y, et al : Purification of human urinary CSF by high performance liquid chromatography. J Chromato $344: 339-3441985$

3) Wong GG, Takaku F, Motoyoshi K, et al : Human CSF-1: Molecular cloning and expression of $4-\mathrm{kb}$ cDNA encoding the human urinary protein. Science 235: 1504-1508 1987

4) Suzu S, Yanai N, Motoyoshi K, et al : Characterization of macrophage colony-stimulating factor in body fluids by immunoblot analysis. Blood 77 : 2160-2165 1991

5) Suzu S, Ohtsuki T, Motoyoshi K, et al : Identification of a high molecular weight $\mathrm{M}-\mathrm{CSF}$ as a glycosaminoglycan-containing species. J Biol Chem $267:$ 4345-4348 1992

6) Suzu S, Ohtsuki T, Motoyoshi K, et al : Biological activity of a proteoglycan form of $\mathrm{M}-\mathrm{CSF}$ and its binding to type $\mathrm{V}$ collagen. J Biol Chem 267 : 16812-16815 1992

7) Motoyoshi K, Yoshida K, Hatake K, et al : Recombinant and native human urinary colony-

\section{M-CSF の卯巣癌での 2 重盲検試験}

1992年から1996年にかけて実施された M-CSF と プラセボを用いた 2 重盲検試験では，M-CSF 投与 が化療第 2 第 3 クールの完遂日数の短縮と感染日 数の短縮をもたらすことが統計的有意差をもって証 明された ${ }^{25)}$ 。さらに完全腫瘍摘出手術が行われた患 者群においては，M-CSF 群の再発率 $(11.0 \%)$ の方 がプラセボ群の再発率 $(29.5 \%)$ より統計的有意 $(\mathrm{p}=0.0189)$ に低いことが証明された。

これらの結果は M-CSF を化学療法と併用するこ とによって白血病や卵巣癌の再発を防止できること を示している。これまでの臨床試験では GM-CSF や G-CSF には再発防止効果がないことが示されて おり，M-CSF は今後白血病や癌の治療に必須の薬 剂となろう。

\section{献}

stimulating factor directly augments $\mathrm{G}^{-}$and GM-CSF production of human peripheral blood monocytes. Exp Hematol 17:68-71 1989

8) Hashimoto S, Yoda M, Motoyoshi K, et al : Interleukin 8 production in human monocytes. Exp Hematol 24 : 123-128 1996

9) Douzono M, Suzu S, Motoyoshi K, et al : Augmentation of cancer chemotherapy by preinjection of human M-CSF in L1210 leukemic cellinoculated mice. Jpn J Cancer Res $86: 315-321$ 1995

10) Sakurai T, Suzu S, Motoyoshi K, et al: Induction of TNF in mice by recombinant human $\mathrm{M}$ -CSF. Jpn J Cancer Res 85 : 80-85 1994

11) Sakurai T, Yamada M, Motoyoshi K, et al: Antimetastatic effect of rhM-CSF against lung and liver metastatic B16 melanoma. Cancer lmmunol lmmunother 1997 in press

12) Saito $S$, Saito $M$, Motoyoshi $K$, et al: Human $\mathrm{M}$-CSF induces the differentiation of trophoblast. Growth Factors 9:11-19 1993

13) Saito S, Motoyoshi $K$, Ichijo $M$, et al: High serum M-CSF level during pregnancy. Int $\mathrm{J}$ Hematol $20: 879-8851992$

14) Yoshida H, Hayashi S, Kunisada $T$, et al: The murine mutation osteopetrosis is in the coding 
region of the M-CSF gene. Nature $345: 442-444$ 1990

15) Tanaka S, Takahashi $\mathrm{N}$, Udagawa $\mathrm{N}$, et al: Macrophage colony-stimulating factor is indispensable for both proliferation and differentiation of osteoclast progenitors. J Clin Invest 91 : 257-263 1993

16) Motoyoshi K, Takaku F:Serum cholesterollowering activity of human macrophage colony -stimulating factor. Lancet ii : 326-327 1989

17) Shimano $H$, Yamada $N$, Motoyoshi $K$, et al : Human M-CSF enhances the clearance of lipoproteins containing apolipoprotein B 100 via both low density lipoprotein receptor-dependent and -independent pathways in rabbits. $\mathrm{J}$ Biol Chem $265: 12869-128751990$

18) Inoue I, Inaba $T$, Motoyoshi $K$, et al: Macrophage CSF prevents the progression of atherosclerosis in Watanabe heritable hyperlipidemic rabbits. Atherosclerosis 93:245-254 1992

19) Kimura F, Suzu S, Motoyoshi K, et al : Structural analysis of proteoglycan macrophage colony-stimulating factor. J Biol Chem 269 : 19751197561994
20) Ohtsuki T, Hatake K, Motoyoshi K, et al : Immunohistochemical identification of proteoglycan form of macrophage colony-stimulating factor on bone surface. Calcif Tissue Int $57: 213$ $-2171995$

21) Suzu S, Inaba $T$, Motoyoshi $K$, et al : Proteoglycan form of M-CSF binds low density lipoprotein. J Clin Invest 94 : 1637-1641 1994

22) Suzu S, Kimura F, Motoyoshi K, et al: Direct interaction of proteoglycan $\mathrm{M}-\mathrm{CSF}$ and basic fibroblast gropwth factor. Blood $83: 3113-3119$ 1994

23) Ohno R, Miyawaki S, Motoyoshi K, et al: Human urinary $\mathrm{M}-\mathrm{CSF}$ reduces the incidence and duration of febrile neutropenia and shortens the period required to finish three courses of intensive consolidation therapy in acute myeloid leukemia. J Clin Oncol 15:2954-2965 1997

24）元吉和夫, 宮脇修一, 鼻 清彦ら：M-CSF 臨床応用 の将来展望 臨床血液38:375-379 1997

25）西村治夫, 薬師寺道明, 元吉和夫ら：卵巣悪性腫焬化 学療法におけるヒトマクロファージコロニ一刺激因 子（P-100）の有用性に関する二重盲検群間比較試 験 Oncology \& Chemotherapy 13:161-169 1997 